\title{
Growth, Yield and Plant Quality of Sweet Basil (Ocimum Basilicum L.) as Affected by Nitrogen and Potassium Doses Under Neutral and Acidic Soil Condition
}

\author{
Princess Vergelle A. Escultor ${ }^{1 *}$ and Anabella B. Tulin ${ }^{2}$
}

\section{ABSTRACT}

Considering the great significance of basil for food and medicinal purposes, it is important to study the proper culture and management of sweet basil. A pot experiment was done to: (a) evaluate the effects of increasing doses of nitrogen and potassium application on the growth, yield, and plant quality of sweet basil; (b) determine the optimum rate of nitrogen and potassium combination for sweet basil and (c) assess the effects of different levels of nitrogen and potassium fertilizers on the chemical properties of acidic and neutral soil. There were eight treatments consisting of different levels of $\mathrm{N}$ and $\mathrm{K}_{2} \mathrm{O}$ added into neutral and acidic soil. These treatments were the following: $\mathrm{T}_{1}-$ Control (No fertilizer), $\mathrm{T}_{2}-60-60-60 \mathrm{~kg} / \mathrm{ha} \mathrm{N}-\mathrm{P}_{2} \mathrm{O}_{5}-$ $\mathrm{K}_{2} \mathrm{O}$ (RR), $\mathrm{T}_{3}-0-60-60 \mathrm{~kg} / \mathrm{ha} \mathrm{N}-\mathrm{P}_{2} \mathrm{O}_{5}-\mathrm{K}_{2} \mathrm{O}, \mathrm{T}_{4}-120-60-60 \mathrm{~kg} / \mathrm{ha} \mathrm{N}-\mathrm{P}_{2} \mathrm{O}_{5}-\mathrm{K}_{2} \mathrm{O}, \mathrm{T}_{5}-180-$ $60-6 / \mathrm{hO} \mathrm{kg} / \mathrm{ha} \mathrm{N}-\mathrm{P}_{2} \mathrm{O}_{5}-\mathrm{K}_{2} \mathrm{O}, \mathrm{T}_{6}-60-60-0 \mathrm{~kg} / \mathrm{ha} \mathrm{N}-\mathrm{P}_{2} \mathrm{O}_{5}-\mathrm{K}_{2} \mathrm{O}, \mathrm{T}_{7}-60-60-120 \mathrm{~kg} / \mathrm{ha} \mathrm{N}-$ $\mathrm{P}_{2} \mathrm{O}_{5}-\mathrm{K}_{2} \mathrm{O}$, and $\mathrm{T}_{8}-60-60-180 \mathrm{~kg} / \mathrm{ha} \mathrm{N}-\mathrm{P}_{2} \mathrm{O}_{5}-\mathrm{K}_{2} \mathrm{O}$.

The results showed that the application of $\mathrm{T}_{3}\left(0-60-60 \mathrm{~kg} / \mathrm{ha} \mathrm{N}-\mathrm{P}_{2} \mathrm{O}_{5}-\mathrm{K}_{2} \mathrm{O}\right)$ has increased plant height, number of primary branches, root length, fresh and dry weights of leaf, herbage yield, and root weight under neutral soil condition. Meanwhile, optimum application of $\mathrm{N}$ and $\mathrm{K}\left(60-60-60 \mathrm{~kg} / \mathrm{ha} \mathrm{N}-\mathrm{P}_{2} \mathrm{O}_{5}-\mathrm{K}_{2} \mathrm{O}\right)$ influenced sweet basil's quality in terms of its chlorophyll content (Chlorophyll $a$ and b). Moreover, increased chemical properties of neutral and acidic soil were significantly affected by application of $\mathrm{T}_{5}\left(180-60-60 \mathrm{~kg} / \mathrm{ha} \mathrm{N}-\mathrm{P}_{2} \mathrm{O}_{5}-\mathrm{K}_{2} \mathrm{O}\right), \mathrm{T}_{7}(60-60-$ $\left.120 \mathrm{~kg} / \mathrm{ha} \mathrm{N}-\mathrm{P}_{2} \mathrm{O}_{5}-\mathrm{K}_{2} \mathrm{O}\right)$, and $\mathrm{T}_{8}\left(60-60-180 \mathrm{~kg} / \mathrm{ha} \mathrm{N}-\mathrm{P}_{2} \mathrm{O}_{5}-\mathrm{K}_{2} \mathrm{O}\right)$. Most importantly, application of $\mathrm{T}_{3}\left(0-60-60 \mathrm{~kg} / \mathrm{ha} \mathrm{N}-\mathrm{P}_{2} \mathrm{O}_{5}-\mathrm{K}_{2} \mathrm{O}\right), \mathrm{T}_{4}\left(120-60-60 \mathrm{~kg} / \mathrm{ha} \mathrm{N}-\mathrm{P}_{2} \mathrm{O}_{5}-\mathrm{K}_{2} \mathrm{O}\right), \mathrm{T}_{6}$ (60-60-0 kg/ha N- $\left.\mathrm{P}_{2} \mathrm{O}_{5}-\mathrm{K}_{2} \mathrm{O}\right)$, and $\mathrm{T}_{8}\left(60-60-180 \mathrm{~kg} / \mathrm{ha} \mathrm{N}-\mathrm{P}_{2} \mathrm{O}_{5}-\mathrm{K}_{2} \mathrm{O}\right)$ has influenced \% $\mathrm{N}, \mathrm{P}$, and $\mathrm{K}$ concentrations in basil leaf significantly. The optimum combination of $\mathrm{N}$ and $\mathrm{K}$ that was highly favorable under both neutral and acidic condition was $\mathrm{T}_{3}(0-60-$ $60 \mathrm{~kg} / \mathrm{ha} \mathrm{N}-\mathrm{P}_{2} \mathrm{O}_{5}-\mathrm{K}_{2} \mathrm{O}$ ), indicating that sweet basil needs small amounts of $\mathrm{N}$ for its growth and yield.

Keywords: sweet basil, Nitrogen, Potassium, neutral and acidic soil

\footnotetext{
${ }^{1}$ Department of Soil Science, Visayas State University, Visca, Baybay City, Leyte, Philippines
}

${ }^{2}$ Office of the Graduate School, Visayas State University, Visca, Baybay City, Leyte, Philippines 


\section{INTRODUCTION}

Sweet basil (Ocimum basilicum L.) is an important aromatic plant cultivated in many parts of the world for its essential oil. Some of the more popular basils include sweet, specialty fragrant (cinnamon, lemon and Thai/anise), purple-leaved, bush, and miniature or dwarf. Holy basil in particular has been found to reduce circulating glucose levels in both normal and diabetic laboratory animals as well as in diabetic humans. These results, particularly the evidence from human experiments, are hopeful and could add credibility to the medicinal use of basil in ancient cultures (Centers for Disease Control and Prevention 2008). However, a study on the cultural management of this plant, specifically on its nutrient requirements and the types of soils that are suitable for its growth and development, has not been conducted. This is a novel development which needs to be supported by the latest agricultural innovations.

In recent years, innovations and researches are mainly focused on the tremendous development of high yielding varieties. However, majority of the farmers have still been producing yields way below than what has been obtained in research stations. As a result, the farmers' produce has decreased while demand for food has increased rapidly due to rapid growth of population and accessibility to food. These reasons are attributed to unfavorable climate conditions and improper or insufficient cultural management techniques (i.e control of pest and diseases and fertilizer application). Most farmers and growers lack the technical know-how with regards to proper use and handling of fertilizers which often result to continuous depletion of the essential elements needed by plants such as nitrogen $(\mathrm{N})$, phosphorus $(\mathrm{P})$ and potassium $(\mathrm{K})$ and other micronutrients thus, optimum rate for fertilization is required to augment its production (Cabanilla 1996; O'Sullivan et al 1997).

Nitrogen, which is called a yield-stimulating nutrient, affects both volumes of yields and the chemical composition of yield components (Chen et al 2004; Nurzyñska-Wierdak, 2006; Biesiada \& Kuœ, 2010). The effective use of $\mathrm{N}$ fertilizers to achieve maximum yields while reducing the amount of nitrate- $\mathrm{N}$ in the soil is very important in both developed and developing countries (Ankumah 2003).

Aside from $\mathrm{N}$, potassium $(\mathrm{K})$ is considered as an essential plant nutrient which is commonly lacking in many fields. According to Matsumoto et al (2013), increasing potassium doses contributed to the elevation of protein and total nitrogen concentration, as well as decreased the ammonium and nitrate nitrogen in basil.

Considering the great significance of basil for food and medicinal purposes, it is important to study the proper culture and management of sweet basil. This will pave the way for its massive cultivation to meet the high demand for the crop. In VSU, there has been no study focusing on the cultural management of sweet basil, specifically on its nutrient and soil type requirements as well as its effects on the growth, yield, and quality. Thus, this study was conducted to: (a) evaluate the effects of increasing doses of nitrogen and potassium application on the growth, yield, and plant quality of sweet basil; (b) determine the optimum rate of nitrogen and potassium combination for sweet basil and; (c) assess the effects of different levels of nitrogen and potassium fertilizers on the chemical properties of acidic and neutral soil. 


\section{MATERIALS AND METHODS}

\section{Soil Chemical Analysis}

Bulk samples of acidic and neutral soil were collected from the surface $(0-20$ $\mathrm{cm}$ layer) at two different locations of the Visayas State University, Visca, Baybay City, Leyte. The samples were thoroughly mixed, sterilized, and sieved with a $10 \mathrm{~mm}$ wire screen to remove gravel and big root fractions. Composite soil samples of about $1 \mathrm{~kg}$ were collected, air-dried, pulverized, and sieved using 2-mm wire mesh. This served as the initial composite sample and submitted to the Central Analytical Service Laboratory (CASL), Philippine Root Crop Research Center (PhilRootcrops), VSU, Visca, Baybay City, Leyte for analysis of the following parameters: soil pH (Potentiometric method using 1:2.5 soil water ratio ISRIC 1995), organic matter (\%) (Modified Walkley Black Method, Nelson and Sommers 1982), total N (\%) (Kjedahl Method, USDA 2004), available phosphorous (Bray No. 2 Method, Jackson 1958), and exchangeable $\mathrm{K}$ (extracted using $1 \mathrm{~N} \mathrm{NH}_{4} \mathrm{OAc}$ and quantified by the used of Atomic Absorption Spectrophotometer Varian 220 FS). After harvest, the soil samples were collected from each pot. These were air-dried, sieved, and analyzed for the determination of the same soil parameters mentioned above.

\section{Experimental Design and Treatments}

The pot experiment was conducted at the Department of Soil Science (DSS) screenhouse to protect plant samples from excessive rainfall at Visca, Baybay City, Leyte. The experiment was carried out in Factorial arranged in Randomized Complete Block Design with eight (8) treatments, replicated three (3) times with three (3) sample plants in each replication. The different treatment combinations were designated as follows: Factor A: Main Plot (Type of Soil) (a) $\mathrm{M}_{1}=$ Acidic Soil (b) $\mathrm{M}_{2}=$ Neutral Soil and Factor B: Sub-plot ( $\mathrm{N}$ and $\mathrm{K}_{2} \mathrm{O}$ levels), $\mathrm{T}_{1}-$ Control (No fertilizer), $\mathrm{T}_{2}-60-60-60 \mathrm{~kg} / \mathrm{ha} \mathrm{N}-\mathrm{P}_{2} \mathrm{O}_{5}-\mathrm{K}_{2} \mathrm{O}$ (RR), $\mathrm{T}_{3}-0-60-60 \mathrm{~kg} / \mathrm{ha} \mathrm{N}-\mathrm{P}_{2} \mathrm{O}_{5}-\mathrm{K}_{2} \mathrm{O}, \mathrm{T}_{4}-120-60-60$ $\mathrm{kg} / \mathrm{ha} \mathrm{N}-\mathrm{P}_{2} \mathrm{O}_{5}-\mathrm{K}_{2} \mathrm{O}, \mathrm{T}_{5}-180-60-60 \mathrm{~kg} / \mathrm{ha} \mathrm{N}-\mathrm{P}_{2} \mathrm{O}_{5}-\mathrm{K}_{2} \mathrm{O}, \mathrm{T}_{6}-60-60-0 \mathrm{~kg} / \mathrm{ha} \mathrm{N}-\mathrm{P}_{2} \mathrm{O}_{5}-\mathrm{K}_{2} \mathrm{O}$, $\mathrm{T}_{7}-60-60-120 \mathrm{~kg} / \mathrm{ha} \mathrm{N}-\mathrm{P}_{2} \mathrm{O}_{5}-\mathrm{K}_{2} \mathrm{O}$ and $\mathrm{T}_{8}-60-60-180 \mathrm{~kg} / \mathrm{ha} \mathrm{N}-\mathrm{P}_{2} \mathrm{O}_{5}-\mathrm{K}_{2} \mathrm{O}$. The pot distance was $0.4 \mathrm{~m} \times 0.4 \mathrm{~m}$.

\section{Cultural Management Practices}

Three seeds of sweet basil (var. Genovese) were sown in each cell in the propagation tray. Partial shading was done to minimize the exposure of seedlings to direct sunlight. Thinning was done as the seedlings emerged (three pairs of leaves). After 15 days, transplanting was done leaving one healthy seedling per pot. A total of 144 polyethylene pots, with five (5) perforations at the bottom were used and placed at the DSS screen house. Each pot was filled with $3 \mathrm{~kg}$ of air-dried soils (acid and neutral soil). Sufficient amount of water was added to keep the moisture at field capacity.

Urea (46-0-0), solophos (0-20-0), and muriate of potash (0-0-60) are commercially available inorganic fertilizers. In order to satisfy the recommended rate of sweet basil at $60-60-60 \mathrm{~kg} \mathrm{~N}-\mathrm{P}_{2} \mathrm{O}_{5}-\mathrm{K}_{2} \mathrm{O}$ per ha, a corresponding amount of 3.91-9.00-3.00 g per pot of urea, solophos, and muriate of potash were added. 
All fertilizers were added to the pots two (2) weeks after transplanting by boring four (4) holes around each plant (Table 1).

Insecticide and fungicide were sprayed at weekly intervals when mechanical damage and fungal diseases on sweet basil were found and identified. Spraying was done starting from one week after transplanting up to the plants' first flowering. Weeds were removed regularly by hand. The experimental plants were watered at field capacity to avoid waterlogging of pots.

The first harvest was done 54 days from transplanting. Once the plants have developed six to eight pairs of true leaves, harvesting may begin. Sweet basil plants were cut $1 \mathrm{~cm}$ above the ground. The stem, leaves, and roots were separated. These were washed with tap water, then distilled water, and were blotted dry and weighed for fresh plant biomass. At harvest, plant leaves were weighed, then placed in labelled paper bags for oven drying at $70^{\circ} \mathrm{C}$ for three (3) days or until constant weight was attained. After which, these were weighed again to get the dry matter weight and ground to a particle size of $1 \mathrm{~mm}$ using a Wiley Mill Grinder. The ground tissue samples were used to determine total N (\%), total P (\%), and total K(\%).

Table 1. Amount of fertilizer added in each pot

\begin{tabular}{lccc}
\hline & \multicolumn{3}{c}{ FERTILIZER (g/ pot) } \\
\hline $\mathrm{T}_{1}-$ Control (No fertilizer) & 0.00 & 0.00 & 0.00 \\
$\mathrm{~T}_{2}-60-60-60 \mathrm{~kg} / \mathrm{haN}-\mathrm{P}_{2} \mathrm{O}_{5}-\mathrm{K}_{2} \mathrm{O}$ & 3.91 & 9.00 & 3.00 \\
$\mathrm{~T}_{3}-0-60-60 \mathrm{~kg} / \mathrm{haN}-\mathrm{P}_{2} \mathrm{O}_{5}-\mathrm{K}_{2} \mathrm{O}$ & 0.00 & 9.00 & 3.00 \\
$\mathrm{~T}_{4}-120-60-60 \mathrm{~kg} / \mathrm{haN}-\mathrm{P}_{2} \mathrm{O}_{5}-\mathrm{K}_{2} \mathrm{O}$ & 7.83 & 9.00 & 3.00 \\
$\mathrm{~T}_{5}-180-60-60 \mathrm{~kg} / \mathrm{haN}-\mathrm{P}_{2} \mathrm{O}_{5}-\mathrm{K}_{2} \mathrm{O}$ & 11.74 & 9.00 & 3.00 \\
$\mathrm{~T}_{6}-60-60-0 \mathrm{~kg} / \mathrm{haN}-\mathrm{P}_{2} \mathrm{O}_{5}-\mathrm{K}_{2} \mathrm{O}$ & 3.91 & 9.00 & 0.00 \\
$\mathrm{~T}_{7}-60-60-120 \mathrm{~kg} / \mathrm{haN}-\mathrm{P}_{2} \mathrm{O}_{5}-\mathrm{K}_{2} \mathrm{O}$ & 3.91 & 9.00 & 6.00 \\
$\mathrm{~T}_{8}-60-60-180 \mathrm{~kg} / \mathrm{haN}-\mathrm{P}_{2} \mathrm{O}_{5}-\mathrm{K}_{2} \mathrm{O}$ & 3.91 & 9.00 & 9.00 \\
\hline
\end{tabular}

\section{Data Gathered}

Growth, yield, and plant quality parameters were gathered. These were plant height $(\mathrm{cm})$, number of primary branches per plant, root length $(\mathrm{cm})$, fresh leaf weight/plant (g/pot), dry leaf weight/plant (g/pot), fresh herbage yield at harvest (g/pot), dry matter at harvest (g/pot), fresh root weight (g/pot), dry root weight (g/pot), chlorophyll contents (SPAD Chlorophyll meter, Minolta Brand), and chlorophyll A and B contents analysis (Porra et al 1989).

\section{Statistical Tool}

All the data were encoded in Microsoft Excel and subjected to statistical analysis of variance (ANOVA) using Statistix Software (ver 8.1). If found significant, treatment means were separated using the Honest Significant Difference or Tukey's test at $5 \%$ Level of Significance. 


\section{RESULTS AND DISCUSSIONS}

\section{General Observations}

One week after transplanting, sweet basil planted on acidic and neutral soil applied with different levels nitrogen and potassium fertilizers were more or less the same in terms of growth (e.g. plant height) as shown in Figure 1a. At the later stage of growth (weeks 3-7), a considerable increase in height was observed in plant samples supplied with optimum amount of inorganic fertilizer (Fig. 1b). Moreover, yellowing of leaves was noted in plants grown under acidic and neutral soil without any fertilizer (e.g. control and $\mathrm{T}_{3}$ ). Symptoms of chlorosis were also observed in some of the plant samples $\left(T_{1}, T_{5}\right.$, and $\left.T_{8}\right)$. Signs of larval infestation were also observed randomly among the plants. However, three weeks after transplanting, severe yellowing of leaves and wilting were observed particularly in the plants without any fertilizer (i.e. control) and with the highest dose of $\mathrm{N}$ and $\mathrm{K}\left(\mathrm{T}_{5}\right.$ and $\left.\mathrm{T}_{8}\right)$.

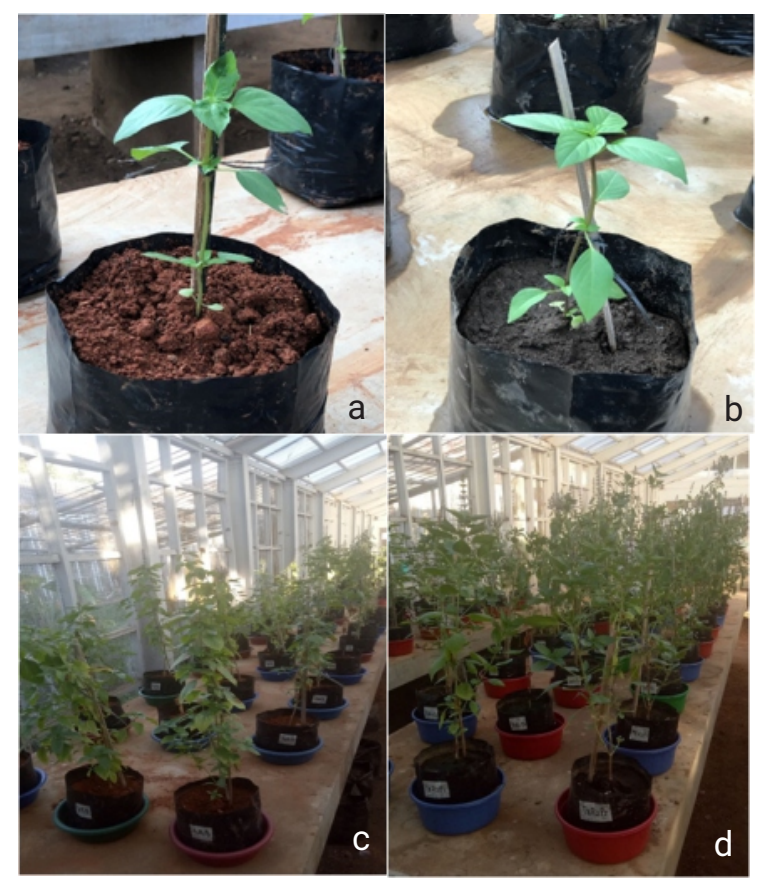

Legend:

$\mathrm{T}_{1}-$ Control (No fertilizer)

$\mathrm{T}_{2}-60-60-60 \mathrm{~kg} / \mathrm{haN}-\mathrm{P}_{2} \mathrm{O}_{5}-\mathrm{K}_{2} \mathrm{O}$

$\mathrm{T}_{3}-0-60-60 \mathrm{~kg} / \mathrm{haN}-\mathrm{P}_{2} \mathrm{O}_{5}-\mathrm{K}_{2} \mathrm{O}$

$\mathrm{T}_{4}-120-60-60 \mathrm{~kg} / \mathrm{haN}-\mathrm{P}_{2} \mathrm{O}_{5}-\mathrm{K}_{2} \mathrm{O}$
$\mathrm{T}_{5}-180-60-60 \mathrm{~kg} / \mathrm{haN}-\mathrm{P}_{2} \mathrm{O}_{5}-\mathrm{K}_{2} \mathrm{O}$

$\mathrm{T}_{6}-60-60-0 \mathrm{~kg} / \mathrm{ha} \mathrm{N}-\mathrm{P}_{2} \mathrm{O}_{5}-\mathrm{K}_{2} \mathrm{O}$

$\mathrm{T}_{7}-60-60-120 \mathrm{~kg} / \mathrm{haN}-\mathrm{P}_{2} \mathrm{O}_{5}-\mathrm{K}_{2} \mathrm{O}$

$\mathrm{T}_{8}-60-60-180 \mathrm{~kg} / \mathrm{haN}-\mathrm{P}_{2} \mathrm{O}_{5}-\mathrm{K}_{2} \mathrm{O}$

Figure 1. Sweet basil grown in acidic and neutral soil at 1 week after transplanting (WAT- (a) \& (b)) and at harvest ((c)\&(d)) 
Growth, Yield, and Plant Quality of Sweet Basil

\section{Effects of Nitrogen and Potassium on the Growth of Sweet Basil}

\section{a. Plant Height}

Figure 2a shows the plant height of sweet basil at harvest under acidic and neutral soil as affected by different levels of $\mathrm{N}$ and $\mathrm{K}$ fertilizers. The results showed that a constant increase in plant height from week 1 to 7 was observed in plants under neutral soil condition, specifically $T_{3}, T_{2}, T_{6}, T_{7}$, and acidic condition $\left(T_{3}\right)$. Sweet basil planted on neutral soil had the highest plant height from week 1 to 7 . However, on weeks $1,2,4,5$, and 6 , there were significant differences among treatments regardless of the soil $\mathrm{pH}$ condition. On the other hand, it was found that the highest plant height on week 7 was consistently observed in $T_{3}$ (e.g. Acidic- $66.00 \mathrm{~cm}$ \& Neutral- $74.00 \mathrm{~cm}$ ) for both soil conditions. Regardless of the soil condition, the application of 0-60- $60 \mathrm{~kg} / \mathrm{ha} \mathrm{N}-\mathrm{P}_{2} \mathrm{O}_{5}-\mathrm{K}_{2} \mathrm{O}\left(\mathrm{T}_{3}\right)$ increased the plant height of sweet basil. Overall, good performance of sweet basil was observed in neutral soil (Fig. 3). The highest plant height was obtained in $\mathrm{T}_{3}$ with no $\mathrm{N}$. This is significantly different from $\mathrm{T}_{5}$ applied with $180 \mathrm{~kg} / \mathrm{ha} \mathrm{N}$. This shows that higher doses of $\mathrm{N}$ and $\mathrm{K}$ applied to sweet basil could decrease plant height.

\section{b. Number of Primary Branches}

Figure $2 \mathrm{~b}$ shows the primary branches of sweet basil at harvest as affected by different nitrogen and potassium doses under different $\mathrm{pH}$ conditions. The highest number of primary branches was observed in $\mathrm{T}_{6}(18)$ under neutral soil condition (Fig. 3). Subsequently, the lowest primary branches were observed in $\mathrm{T}_{1}$ (control). This shows that high $\mathrm{N}$ and $\mathrm{K}$ doses could decrease primary branches of sweet basil $\left(T_{1}, T_{4}, T_{5}\right.$ and $\left.T_{8}\right)$. Sweet basil produced an abundant number of primary branches mainly in neutral soil. Similarly, as reported by Nurzyńska-Wierdak (2012), the number of basil plant branching was on average 12.5 pieces per plant and significantly depended on the cultivar and dose of applied nitrogen. Moreover, the basil plants had different numbers of branchings (5.2-45.5 pieces per plant) (Kandil et al 2009; Said Al Ahl \& Mahmoud 2010; Nurzyńska-Wierdak \& Borowski 2011) which was related to their height and habit. However, that number decreased as an effect of salt stress (Said-Al Ahl \& Mahmoud 2010) which proves the sensitivity of basil to excessive concentration of nutrients in the substratum reported at medium and the highest nitrogen doses.

\section{c. Root Length}

Roots are useful in the uptake of nutrients for plants. They absorb water and nutrients from the soil and translocate them to plant tops (Merrill et al 1996; Sainju et al 2005 \& Stone et al 2001) through mass flow, diffusion, or root interception. As much as $7-43 \%$ of the total aboveground and belowground plant biomass can be contributed by roots (Kuo et al 1997). Figure 2c shows that the highest root length was observed in $\mathrm{T}_{1}$ (control) with the value $27.33 \mathrm{~cm}$ (neutral). Root length of sweet basil increased under neutral soil condition even if there were no fertilizers applied. The longer the roots, the greater their capacity to absorb nutrients in the soil. On the other hand, the results revealed that the macronutrient content in water, especially 
$\mathrm{N}$, was relatively high (610-630 $\mu \mathrm{g} / \mathrm{mL}$ ) (Moreno 2018). This can influence the root length of sweet basil especially in $\mathrm{T}_{1}$ (control). However, the shortest root length was observed in $\mathrm{T}_{5}$ and $\mathrm{T}_{8}$, both with the highest rates of $\mathrm{N}$ and $\mathrm{K}$ applied. This could be due to salt injury from application of high doses of fertilizers. High soil salt levels can prevent roots from absorbing adequate water so plants and trees grow poorly (Hanson 2013). Comfort et al (1988) found that high rates of application of $\mathrm{N}$ reduced root growth and depth of rooting in wheat. Moreover, as the level of $\mathrm{K}$ increased, the root length decreased (Fig. 2c).

\section{Effects of Nitrogen and Potassium on the Yield of Sweet Basil}

\section{a. Fresh and Dry Leaf Weights}

Figure $5 \mathrm{a}$ shows the fresh leaf weight of sweet basil. It was found that regardless of soil condition, $\mathrm{T}_{3}\left(0-60-60 \mathrm{~kg} / \mathrm{ha} \mathrm{N}-\mathrm{P}_{2} \mathrm{O}_{5}-\mathrm{K}_{2} \mathrm{O}\right)$ had the highest amount of fresh leaf weight (118 g/pot). It was also observed in $\mathrm{T}_{6}\left(60-60-0 \mathrm{~kg} / \mathrm{ha} \mathrm{N}-\mathrm{P}_{2} \mathrm{O}_{5}\right.$ $\mathrm{K}_{2} \mathrm{O}$ ) with $80.06 \mathrm{~g} /$ pot. Potassium fertilization also affects the growth, as well as basil yield quantity and quality (Rao et al 2007; Nguyen et al 2010). Kandil et al (2009) obtained the highest fresh basil herb yield and the highest basil essential oil yield when the highest NPK rates were applied. However, the results show that with increasing $\mathrm{N}$ application, fresh leaf weight decreased especially in $\mathrm{T}_{4}$ (120-60- 60 $\left.\mathrm{kg} / \mathrm{ha} \mathrm{N}-\mathrm{P}_{2} \mathrm{O}_{5}-\mathrm{K}_{2} \mathrm{O}\right)$ with $33.37 \mathrm{~g} / \mathrm{pot}$, and $\mathrm{T}_{5}\left(180-60-60 \mathrm{~kg} \mathrm{~K} \mathrm{O} / \mathrm{ha} \mathrm{N}-\mathrm{P}_{2} \mathrm{O}_{5}-\mathrm{K}_{2} \mathrm{O}\right)$ with $24.53 \mathrm{~g} /$ pot.

Figure $5 \mathrm{~b}$ shows the dry leaf weight of sweet basil. $\mathrm{T}_{3}$ had the highest dry matter weight (52.77 g/pot) among all treatments under neutral soil condition. Increasing amounts of $\mathrm{N}$ applied (e.g. 120 and $180 \mathrm{~kg} \mathrm{~N} / \mathrm{ha}$ ) could lessen sweet basil's leaf weight and affect its growth. This was due to nitrogen toxicity and salt injury upon addition of too much fertilizer. Plants tend to experience stunted growth, severe yellowing of the leaves, wilting, and death in severe cases. On the other hand, potassium accumulation, reaching a few percent of dry matter, takes place mainly in the leaves. The level of this nutrient is usually higher than that of the other macroelements (Biesiada \& KuĞ 2010; Dzida 2010; Dzida \& Jarosz 2010). Increasing application of $\mathrm{K}$ can decrease leaf weight.

\section{b. Fresh and Dry Herbage Yield}

Sweet basil herbage yield is shown in Figure $5 \mathrm{c}$. Treatment $3(0-60-60 \mathrm{~kg} / \mathrm{ha} \mathrm{N}$ $\mathrm{P}_{2} \mathrm{O}_{5}-\mathrm{K}_{2} \mathrm{O} / \mathrm{ha}$ ) had the highest amount of fresh herbage yield $(216.77 \mathrm{~g} / \mathrm{pot})$ among all treatments including those planted in acidic soil. Sweet basil can obtain high amounts of herbage yield even with $0 \mathrm{~N}$ applied into the soil under neutral soil conditions. The same trend was observed in all treatments under the two soil conditions (Fig. 5d). The higher the amount of $\mathrm{N}$ and $\mathrm{K}$ applied, the lower the herbage yield.

Figure $5 \mathrm{~d}$ shows the dry herbage yield of sweet basil under two soil types applied with different doses of nitrogen and potassium. The same trend was observed for fresh weight (Fig. $5 \mathrm{c}), T_{3}(71.50 \mathrm{~g} / \mathrm{pot})$ had the highest dry matter yield. Whether the nitrogen was limited/deficient, sweet basil could still acquire high amounts of dry herbage yield under neutral soil condition. In a three-year experiment 
(1973-1975) carried out in Poznan, Poland, increasing N-doses $(0-200 \mathrm{~kg} / \mathrm{ha})$ increased the total dry herb yield significantly. At $200 \mathrm{~kg} / \mathrm{ha}$ nitrogen applied increases the yield by $44 \%$ with higher phosphorus and potassium doses, 80 and $160 \mathrm{~kg} / \mathrm{ha}$, respectively (Czabajski 1978).

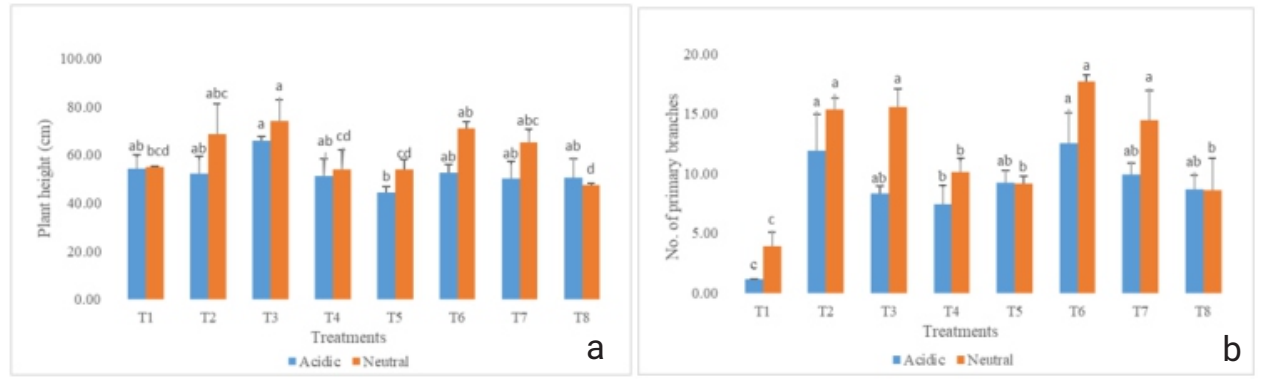

Legend:

$\begin{array}{ll}\mathrm{T}_{1}-\text { Control (No fertilizer) } & \mathrm{T}_{5}-180-60-60 \mathrm{~kg} / \mathrm{ha} \mathrm{N}-\mathrm{P}_{2} \mathrm{O}_{5}-\mathrm{K}_{2} \mathrm{O} \\ \mathrm{T}_{2}-60-60-60 \mathrm{~kg} / \mathrm{ha} \mathrm{N}-\mathrm{P}_{2} \mathrm{O}_{5}-\mathrm{K}_{2} \mathrm{O} & \mathrm{T}_{6}-60-60-0 \mathrm{~kg} / \mathrm{haN}-\mathrm{P}_{2} \mathrm{O}_{5}-\mathrm{K}_{2} \mathrm{O} \\ \mathrm{T}_{3}-0-60-60 \mathrm{~kg} / \mathrm{ha} \mathrm{N}-\mathrm{P}_{2} \mathrm{O}_{5}-\mathrm{K}_{2} \mathrm{O} & \mathrm{T}_{7}-60-60-120 \mathrm{~kg} / \mathrm{ha} \mathrm{N}-\mathrm{P}_{2} \mathrm{O}_{5}-\mathrm{K}_{2} \mathrm{O} \\ \mathrm{T}_{4}-120-60-60 \mathrm{~kg} / \mathrm{ha} \mathrm{N}-\mathrm{P}_{2} \mathrm{O}_{5}-\mathrm{K}_{2} \mathrm{O} & \mathrm{T}_{8}-60-60-180 \mathrm{~kg} / \mathrm{ha} \mathrm{N}-\mathrm{P}_{2} \mathrm{O}_{5}-\mathrm{K}_{2} \mathrm{O}\end{array}$

Figure 2. Growth parameters of sweet basil: (a) plant height (cm); (b) number of primary branches; (c) root length $(\mathrm{cm})$ at harvest as affected by different nitrogen and potassium doses under neutral and acidic soil condition

\section{c. Fresh and Dry Root Weight}

Roots are very important in plant growth. All processes in the soil have direct contact with plant roots most importantly in plant uptake of water and nutrients (e.g. mass flow, diffusion, and root interception). Root morphology is influenced by the amount of $\mathrm{N}$ fertilizer applied (Eghball et al 1993). The bigger the roots, the higher is the capacity to absorb nutrients available for plant use. Figures 13 and 14 show the fresh and dry root weight of sweet basil. $\mathrm{T}_{3}\left(0-60-60 \mathrm{~kg} \mathrm{~N}-\mathrm{P}_{2} \mathrm{O}_{5}-\mathrm{K}_{2} \mathrm{O} / \mathrm{ha}\right)$ under neutral soil condition had the highest fresh root weight $(9 \mathrm{~g} / \mathrm{pot})$. A similar trend for fresh and dry weight (Figs. 5e and 5f) was observed under neutral soil condition. Increasing application of $\mathrm{N}$ and $\mathrm{K}$ could decrease fresh and dry root weight. This was observed in Treatments 4 and 5 in both soil conditions. Small and undesirable appearance of roots were observed. However, good rooting system 
was consistently observed under neutral soil (Fig. 4). Nitrogen improves production of lateral roots and root hairs, as well as increasing rooting depth and root length density deep in the profile (Hansson \& Andren 1987). Nitrogen deficiency also reduces branching and root hairs in cereals and legumes (Baligar et al 1998). On the other hand, $\mathrm{K}$ has been shown to promote the root growth of some vegetable crops (Zhao et al 1991).

\section{Effects of Nitrogen and Potassium on the Plant Quality Sweet Basil}

\section{a. Chlorophyll (SPAD)}

Chlorophyll is a pigment or a chemical compound that absorbs and reflects specific wavelengths of light. Figure 6 a shows that $T_{2}\left(R R 60-60-60 \mathrm{~kg} / \mathrm{ha} \mathrm{N}-\mathrm{P}_{2} \mathrm{O}_{5}-\right.$ $\mathrm{K}_{2} \mathrm{O}$ ) under neutral soil had the highest amount of chlorophyll (e.g. 44.79) among all treatments while the lowest was observed in the control (acidic soil condition). Optimum application of $\mathrm{N}$ for sweet basil could increase chlorophyll content (SPAD) under neutral soil condition. Increasing levels of $\mathrm{N}$ and $\mathrm{K}$ had no significant effect among treatments. This only result to optimum level of $\mathrm{N}$ which increased the chlorophyll present in the leaves. This supports the direct relationship between chlorophyll and $\mathrm{N}$ content. Nitrogen is a major component of chlorophyll, the compound by which plants use sunlight energy to produce sugars from water and carbon dioxide (e.g. photosynthesis). Optimum application of fertilizers, especially $\mathrm{N}$, can increase chlorophyll content. Inadequate $\mathrm{N}$ application leads to a decrease in leaf area (Fernandez et al 1996), chlorophyll content, leaf photosynthesis, biomass production (Zhao \& Oosterhuis 2000), and the loss of yields and qualities. At higher doses, a decreasing value of chlorophyll was observed, similar to what occurred in the study (Masumo et al 2013).

\section{b. Chlorophyll A and B}

The primary pigment of photosynthesis is chlorophyll A. Chlorophyll A absorbs light from the orange-red and violet-blue areas of the electromagnetic spectrum. Figure $6 \mathrm{~b}$ shows that $\mathrm{T}_{2}$ (acidic soil- $6.36 \mathrm{nmol} / \mathrm{mL}$ ), $\mathrm{T}_{4}$ (acidic soil- $5.96 \mathrm{nmol} / \mathrm{mL}$ ), and $\mathrm{T}_{6}$ (neutral soil- $6.48 \mathrm{nmol} / \mathrm{mL}$ ) obtained the highest chlorophyll a value. Optimum addition of $\mathrm{N}$ and $\mathrm{O} \mathrm{kg} \mathrm{K}_{2} \mathrm{O}$ can increase chlorophyll a. Further, chlorophyll $A$ values also increased in treatments with increasing $\mathrm{N}$ and $\mathrm{K}_{2} \mathrm{O}$ levels added to the soil. Treatments 2 and 4 under acidic soil condition could increase chlorophyll $A$ while under neutral soil, $\mathrm{T}_{6}$ significantly increased chlorophyll a.

Chlorophyll B helps in photosynthesis by absorbing light energy. It is more soluble than chlorophyll A in polar solvents because of its carbonyl group. Its color is green, and it primarily absorbs blue light. Figure $6 \mathrm{c}$ shows that $T_{2}$ (60-60- 60 $\left.\mathrm{kg} / \mathrm{ha} \mathrm{N}-\mathrm{P}_{2} \mathrm{O}_{5}-\mathrm{K}_{2} \mathrm{O}\right)(12.54 \mathrm{nmol} / \mathrm{mL})$ had the highest amount of chlorophyll $\mathrm{B}$ under acidic soil condition. However, in neutral soil, highest chlorophyll $B$ was observed in $\mathrm{T}_{6}$ (60-60- $\left.0 \mathrm{~kg} / \mathrm{ha} \mathrm{N}-\mathrm{P}_{2} \mathrm{O}_{5}-\mathrm{K}_{2} \mathrm{O}\right)(12.75 \mathrm{nmol} / \mathrm{mL})$. Optimum amounts of $\mathrm{N}$ under acidic soil could increase chlorophyll $\mathrm{B}$ while $0 \mathrm{~K}_{2} \mathrm{O}$ could increase chlorophyll $\mathrm{B}$ under neutral soil condition. There is a positive correlation between increasing doses of $\mathrm{N}$ and chloroplastidic pigments, with higher coefficients of chlorophyll $\mathrm{b}$ and carotenoids (Politycka \& Golcz 2004). Both chlorophyll A and B were found to be 
Growth, Yield, and Plant Quality of Sweet Basil

the highest in $\mathrm{T}_{2}\left(60-60-60 \mathrm{~kg} / \mathrm{ha} \mathrm{N}-\mathrm{P}_{2} \mathrm{O}_{5}-\mathrm{K}_{2} \mathrm{O}\right)$ under acidic soil condition and $\mathrm{T}_{6}(60-$ $60-0 \mathrm{~kg} / \mathrm{ha} \mathrm{N}-\mathrm{P}_{2} \mathrm{O}_{5}-\mathrm{K}_{2} \mathrm{O}$ ) under neutral soil condition. This signifies the important rates of optimum levels of NPK in the chlorophyll production of sweet basil.

a

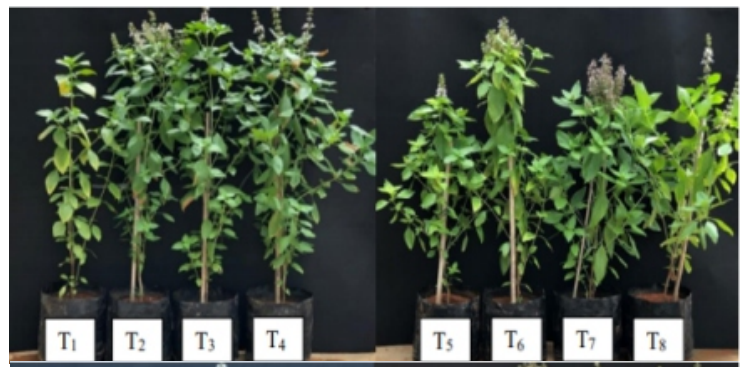

b



Figure 3. Sweet basil at harvest (7 WAT) as affected by different nitrogen and potassium doses under neutral (a) and acidic (b) soil condition

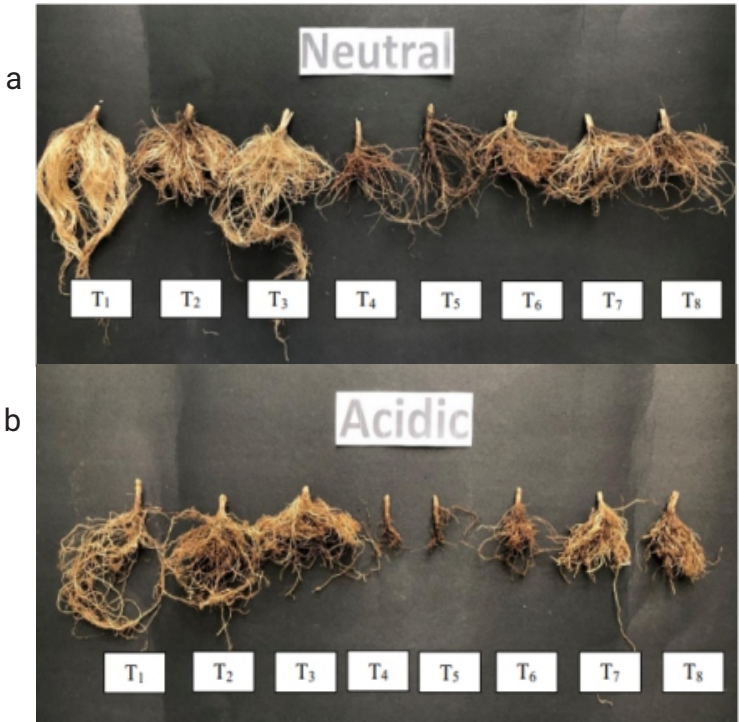

Legend:

$\mathrm{T}_{1}-$ Control (No fertilizer)

$\mathrm{T}_{5}-180-60-60 \mathrm{~kg} / \mathrm{haN}-\mathrm{P}_{2} \mathrm{O}_{5}-\mathrm{K}_{2} \mathrm{O}$

$\mathrm{T}_{2}-60-60-60 \mathrm{~kg} / \mathrm{haN}-\mathrm{P}_{2} \mathrm{O}_{5}-\mathrm{K}_{2} \mathrm{O}$

$\mathrm{T}_{6}-60-60-0 \mathrm{~kg} / \mathrm{haN}-\mathrm{P}_{2} \mathrm{O}_{5}-\mathrm{K}_{2} \mathrm{O}$

$\mathrm{T}_{3}-0-60-60 \mathrm{~kg} / \mathrm{haN}-\mathrm{P}_{2} \mathrm{O}_{5}-\mathrm{K}_{2} \mathrm{O}$

$\mathrm{T}_{4}-120-60-60 \mathrm{~kg} / \mathrm{ha} \mathrm{N}-\mathrm{P}_{2} \mathrm{O}_{5}-\mathrm{K}_{2} \mathrm{O}$

$\mathrm{T}_{7}-60-60-120 \mathrm{~kg} / \mathrm{ha} \mathrm{N}-\mathrm{P}_{2} \mathrm{O}_{5}-\mathrm{K}_{2} \mathrm{O}$

$\mathrm{T}_{8}-60-60-180 \mathrm{~kg} / \mathrm{ha} \mathrm{N}-\mathrm{P}_{2} \mathrm{O}_{5}-\mathrm{K}_{2} \mathrm{O}$

Figure 4. Root length of sweet basil as affected by different nitrogen and potassium doses under neutral (a) and acidic (b) soil condition 

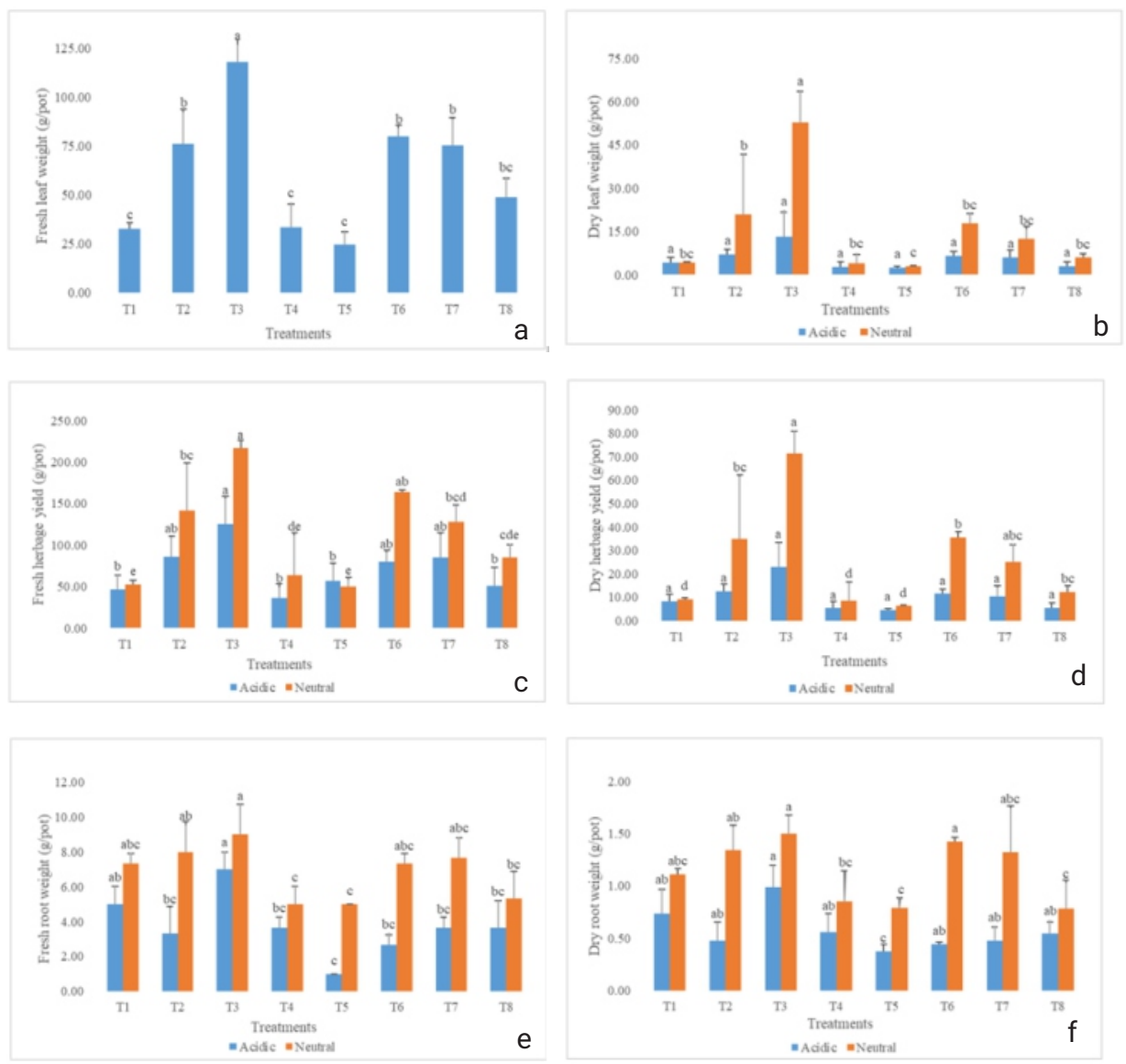

Legend:

$$
\begin{aligned}
& \mathrm{T}_{1}-\text { Control (No fertilizer) } \\
& \mathrm{T}_{2}-60-60-60 \mathrm{~kg} / \mathrm{ha} \mathrm{N}-\mathrm{P}_{2} \mathrm{O}_{5}-\mathrm{K}_{2} \mathrm{O} \\
& \mathrm{T}_{3}-0-60-60 \mathrm{~kg} / \mathrm{ha} \mathrm{N}-\mathrm{P}_{2} \mathrm{O}_{5}-\mathrm{K}_{2} \mathrm{O} \\
& \mathrm{T}_{4}-120-60-60 \mathrm{~kg} / \mathrm{ha} \mathrm{N}-\mathrm{P}_{2} \mathrm{O}_{5}-\mathrm{K}_{2} \mathrm{O}
\end{aligned}
$$

$$
\begin{aligned}
& \mathrm{T}_{5}-180-60-60 \mathrm{~kg} / \mathrm{ha} \mathrm{N}-\mathrm{P}_{2} \mathrm{O}_{5}-\mathrm{K}_{2} \mathrm{O} \\
& \mathrm{T}_{6}-60-60-0 \mathrm{~kg} / \mathrm{haN}-\mathrm{P}_{2} \mathrm{O}_{5}-\mathrm{K}_{2} \mathrm{O} \\
& \mathrm{T}_{7}-60-60-120 \mathrm{~kg} / \mathrm{ha} \mathrm{N}-\mathrm{P}_{2} \mathrm{O}_{5}-\mathrm{K}_{2} \mathrm{O} \\
& \mathrm{T}_{8}-60-60-180 \mathrm{~kg} / \mathrm{ha} \mathrm{N}-\mathrm{P}_{2} \mathrm{O}_{5}-\mathrm{K}_{2} \mathrm{O}
\end{aligned}
$$

Figure 5. Yield parameters of sweet basil: (a) fresh leaf weight (g/pot); (b) dry leaf weight/plant ( $\mathrm{g} / \mathrm{pot}) ;(\mathrm{c})$ fresh herbage yield at harvest ( $\mathrm{g} / \mathrm{pot}) ;(\mathrm{d})$ dry matter at harvest (g/pot); (e) fresh root weight (g/pot); (f) dry root weight $(\mathrm{g} / \mathrm{pot})$ at harvest as affected by different nitrogen and potassium doses under neutral and acidic soil condition 

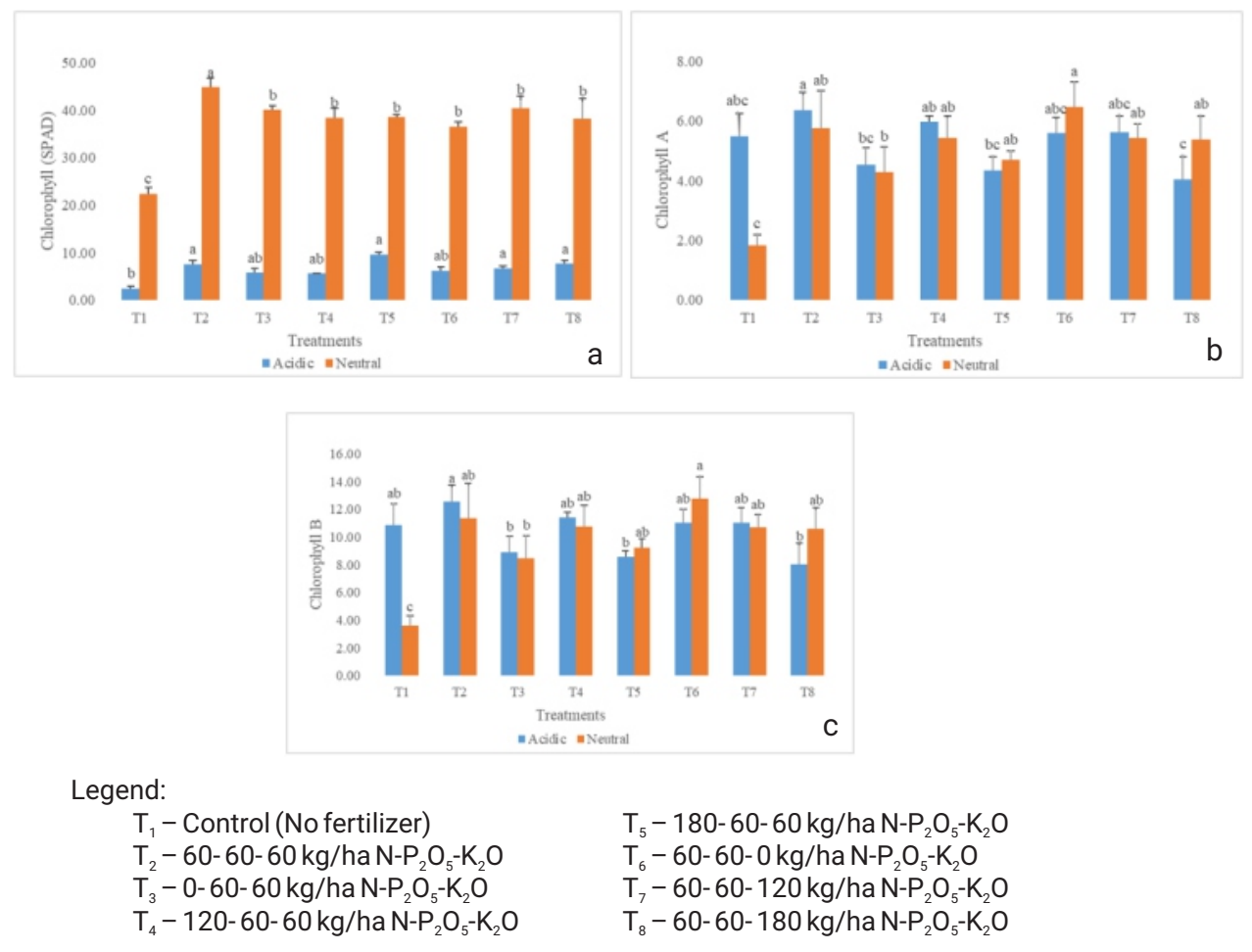

Figure 6. Quality of sweet basil: (a) chlorophyll contents (SPAD); (b) chlorophyll A; (c) chlorophyll B contents at harvest as affected by different nitrogen and potassium doses under neutral and acidic soil condition

\section{Effects of Nitrogen and Potassium on Soil Chemical Properties}

\section{a. SoilpH}

Soil pH is defined as the measure of the concentration of hydrogen ions in the soil solution (Gazey 2016). In addition, it is an indicator of the relative acidity and alkalinity of the soil and is considered as the control of many chemical and biological processes that affect plant nutrient availability. Figure 7a shows the results of soil $\mathrm{pH}$ as affected by different nitrogen and potassium doses under neutral and acidic soil conditions. High soil $\mathrm{pH}$ values were observed in $\mathrm{T}_{6}$ (60-60-0 $\mathrm{kg} / \mathrm{ha} \mathrm{N}-\mathrm{P}_{2} \mathrm{O}_{5}-\mathrm{K}_{2} \mathrm{O}$ ) and $\mathrm{T}_{1}$ (Control) but, these were not significantly different from $\mathrm{T}_{7}$ and $\mathrm{T}_{8}$ in neutral soil. In comparison with its initial soil pH (e.g. 6.64), $\mathrm{pH}$ values were greatly affected upon the addition of nitrogen and potassium fertilizers. The soil pH values in all the treatments, ranging from 5.5 to 6.5 , were considered as good for crop production. In contrast, the initial soil $\mathrm{pH}$ value for acidic soil was 5.22. Upon the addition of different levels of nitrogen and potassium fertilizers, lower soil pH values were consistently noticed under acidic soil condition (e.g. 4.10). The addition of nitrogen and potassium fertilizers can lower soil pH especially at its highest doses (e.g. $\mathrm{T}_{4} \& \mathrm{~T}_{5}$ ). At some point, low soil pH can make Fe and $\mathrm{Al}$ abundant in soil which can cause plant death in severe cases. 


\section{Escultor and Tulin}
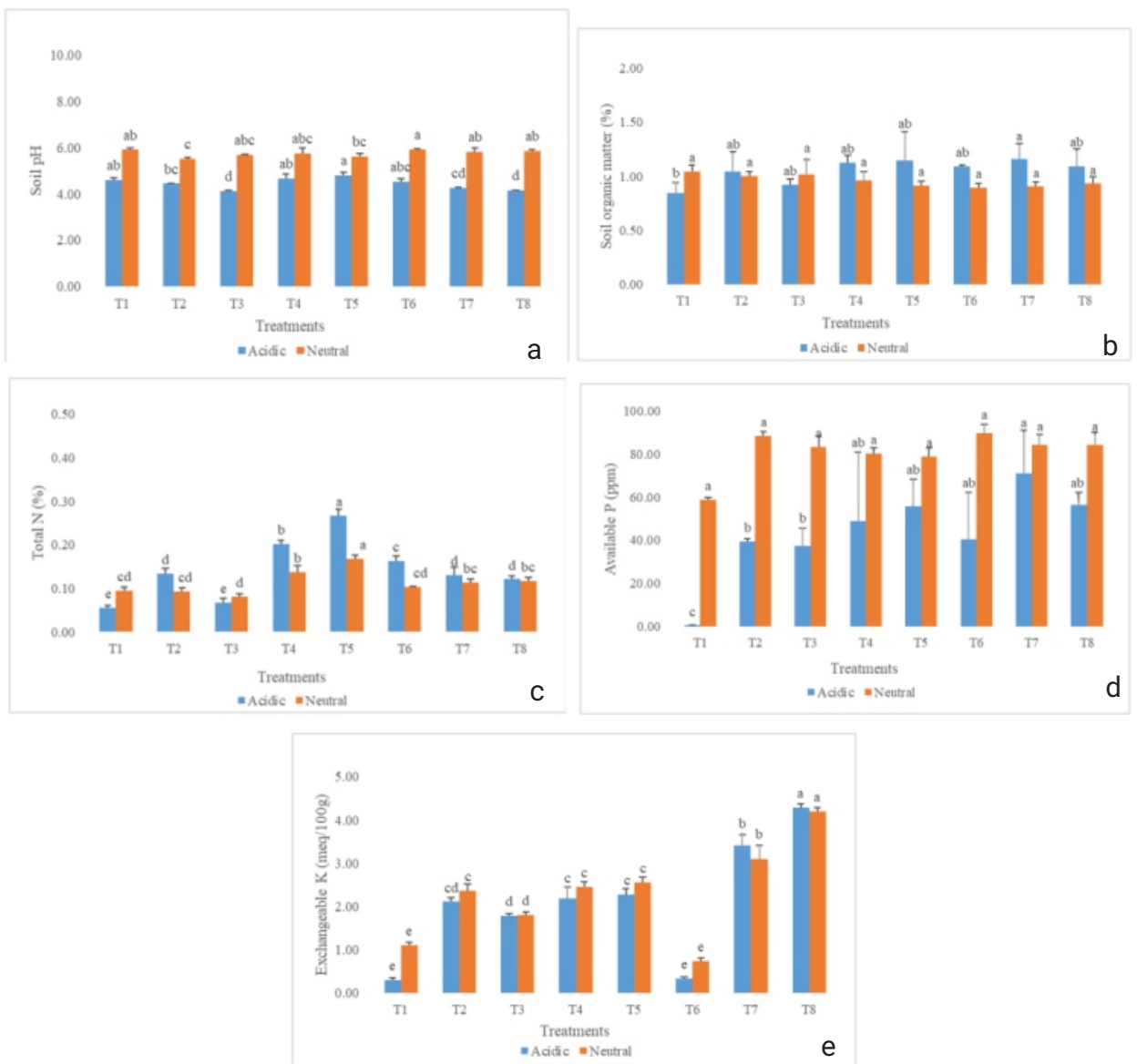

Legend:

$\mathrm{T}_{1}-$ Control (No fertilizer)

$\mathrm{T}_{2}-60-60-60 \mathrm{~kg} / \mathrm{haN}-\mathrm{P}_{2} \mathrm{O}_{5}-\mathrm{K}_{2} \mathrm{O}$

$\mathrm{T}_{5}-180-60-60 \mathrm{~kg} / \mathrm{haN}-\mathrm{P}_{2} \mathrm{O}_{5}-\mathrm{K}_{2} \mathrm{O}$

$\mathrm{T}_{3}-0-60-60 \mathrm{~kg} / \mathrm{ha} \mathrm{N}-\mathrm{P}_{2} \mathrm{O}_{5}-\mathrm{K}_{2} \mathrm{O}$

$\mathrm{T}_{6}-60-60-0 \mathrm{~kg} / \mathrm{ha} \mathrm{N}-\mathrm{P}_{2} \mathrm{O}_{5}-\mathrm{K}_{2} \mathrm{O}$

$\mathrm{T}_{4}-120-60-60 \mathrm{~kg} / \mathrm{ha} \mathrm{N}-\mathrm{P}_{2} \mathrm{O}_{5}-\mathrm{K}_{2} \mathrm{O}$

$\mathrm{T}_{7}-60-60-120 \mathrm{~kg} / \mathrm{haN}-\mathrm{P}_{2} \mathrm{O}_{5}-\mathrm{K}_{2} \mathrm{O}$

$\mathrm{T}_{8}-60-60-180 \mathrm{~kg} / \mathrm{haN}-\mathrm{P}_{2} \mathrm{O}_{5}-\mathrm{K}_{2} \mathrm{O}$

Figure 7. Soil chemical properties: (a) soil pH; (b) soil organic matter (\%); (c) total $\mathrm{N}$ (\%)(d) available P (ppm); (e) exchangeable K (meq/100g) at harvest as affected by different nitrogen and potassium doses under neutral and acidic soil condition 
Growth, Yield, and Plant Quality of Sweet Basil

Table 2. Initial chemical properties of the soil

\begin{tabular}{lcc}
\hline \multirow{2}{*}{ PROPERTY } & \multicolumn{2}{c}{ SAMPLES } \\
\cline { 2 - 3 } & ACIDIC & NEUTRAL \\
\hline $\mathrm{pH}\left(1: 2.5\right.$ soil to $\left.\mathrm{H}_{2} \mathrm{O}\right)$ & 5.22 & 6.64 \\
Soil Organic Matter $(\%)$ & 1.06 & 0.80 \\
Total N (\%) & 0.09 & 0.09 \\
Available P $(\mathrm{ppm})$ & 0.15 & 60.41 \\
Exchangeable K (meq/100g) & 0.31 & 1.18 \\
\hline
\end{tabular}

\section{b. Soil Organic Matter}

Soil organic matter provides most of the cation exchange capacity (CEC) and water holding capacity of surface soils. Figure $7 \mathrm{~b}$ shows the soil organic matter in both acidic and neutral soil as affected by the addition of nitrogen and potassium fertilizers. Initial soil organic matter were $1.06 \%$ and $0.80 \%$ inacidic and neutral soil, respectively. Under acidic and neutral soil, the highest $\mathrm{OM}$ was obtained in $\mathrm{T}_{7}(1.16$ $\%$ \& $0.90 \%)$. The lowest was obtained in the control (0.85) under acidic soil. Moreover, the addition of different levels of $\mathrm{N}$ and $\mathrm{K}$ was not signifcantly different among did not significantly affect the treatments (Fig. 7b). According to Landon 1991, both results were categorized as low organic matter. Even after the addition of nitrogen and potassium, the OM content of the soil remained low, although the levels increased.

\section{c. Total Nitrogen}

Nitrogen is one of the essential elements acquired by plants in ionic form of $\mathrm{NO}_{3}{ }^{-}$and $\mathrm{NH}_{4}{ }^{+}$(Brady 1990). Total $\mathrm{N}$ is deficient mostly in the tropics since it undergoes various losses such as leaching and volatilization (Krofranek et al 2007). Initial total $\mathrm{N}$ for both soil conditions was $0.09 \%$ (Table 1). Highest total nitrogen was observed in $\mathrm{T}_{5}\left(180-60-60 \mathrm{~kg} / \mathrm{ha} \mathrm{N}-\mathrm{P}_{2} \mathrm{O}_{5}-\mathrm{K}_{2} \mathrm{O}\right)$ under acidic soil as shown in Figure 7c. $\mathrm{T}_{5}$ had the highest amount of $\mathrm{N}$ added into the soil. According to Landon 1991 , the value ranges from very low $\mathrm{N}$ to medium amounts of $\mathrm{N}$. Total $\mathrm{N}$ was not significantly influenced by the different levels of $\mathrm{N}$ and $\mathrm{K}$ added into the soil. It was reduced by $0.03 \%$ or $0.04 \%$. Total $\mathrm{N}$ amount in the treated pots was still considered medium (0.27\%) (Landon 1991) even if $\mathrm{N}$ was applied immensely in those pots (e.g. $\left.\mathrm{T}_{5}\right)$.

\section{d. Available Phosphorus}

Phosphorus is one of the least available nutrients to plants and is the most limiting factor for plant growth (Hinsinger 2001). Figure $7 d$ shows the available $P$ in two soil types with the addition of different levels of $\mathrm{N}$ and $\mathrm{K}_{2} \mathrm{O}$. Table 1 shows that the initial available $\mathrm{P}$ were $0.15 \mathrm{ppm}$ and $60.41 \mathrm{ppm}$ in acidic and neutral soil, respectively.

The results show that on neutral soil, the addition of different levels of fertilizers 
can increase available $P$ but this was not significantly different to the other treatments. However, on acidic soil, highest available $P$ was noticed on $T_{7}$ (60- 60 $120 \mathrm{~kg} / \mathrm{ha} \mathrm{N}-\mathrm{P}_{2} \mathrm{O}_{5}-\mathrm{K}_{2} \mathrm{O}$ ). High available $\mathrm{P}$ for sweet basil was observed under neutral soil as $\mathrm{P}$ was available at near neutral soil $\mathrm{pH}$. This implies that sweet basil plants need only optimum amounts of $P$ for plant growth as more phosphorus was found in the soil. Increasing amounts of $\mathrm{N}$ and $\mathrm{K}$ resulted to surplus amount of $\mathrm{P}$ in the soil. However, on neutral soil, very high amounts of $\mathrm{P}$ were noticed compared to acidic soil. Acidic soil tends to have low $P$ because it has been fixed with iron and aluminum in the soil.

\section{d. Exchangeable K(meq/100g)}

Potassium $(\mathrm{K})$ is a major key element essential in the synthesis and translocation of carbohydrates from the top of the plant to the roots (Byju \& Nedunchezhiyan 2004).

Highest exchangeable $\mathrm{K}$ were observed in $\mathrm{T}_{8}\left(60-60-180 \mathrm{~kg} / \mathrm{ha} \mathrm{N}-\mathrm{P}_{2} \mathrm{O}_{5}-\mathrm{K}_{2} \mathrm{O}\right)$ under the two soil types ( Figure 7e). Initial soil exchangeable $\mathrm{K}$ were $0.81 \mathrm{meq} / 100 \mathrm{~g}$ and $1.18 \mathrm{meq} / 100 \mathrm{~g}$ in acidic and neutral soil, respectively (Table 1). According to Landon 1991, values obtained were very high. The same trend was observed from $T_{1}$ to $T_{8}$. The higher the amount of $\mathrm{K}$ fertilizer added into the soil, the higher was the amount of exchangeable K. However, increasing levels of nitrogen added into the soil increased the amount of exchangeable $\mathrm{K}$ in the soil for both soil types. Lowest exchangeable $\mathrm{K}$ was observed both in the control and $\mathrm{T}_{6}\left(60-60-0 \mathrm{~kg} / \mathrm{ha} \mathrm{N}-\mathrm{P}_{2} \mathrm{O}_{5}-\mathrm{K}_{2} \mathrm{O}\right)$ under acidic soil condition. Sweet basil tends to absorb potassium in smaller amounts due to high amounts of exchangeable $\mathrm{K}$ found in the soil. Growing sweet basil only needs $60 \mathrm{~kg} / \mathrm{ha} \mathrm{K}_{2} \mathrm{O} / \mathrm{ha}$. $\mathrm{T}_{7}\left(60-60-120 \mathrm{~kg} / \mathrm{ha} \mathrm{N}-\mathrm{P}_{2} \mathrm{O}_{5}-\mathrm{K}_{2} \mathrm{O}\right.$ and $\mathrm{T}_{8}(60-60-180$ $\mathrm{kg} / \mathrm{ha} \mathrm{N}-\mathrm{P}_{2} \mathrm{O}_{5}-\mathrm{K}_{2} \mathrm{O}$ ) had a surplus supply of $\mathrm{K}$ for sweet basil. Moreover, exchangeable $\mathrm{K}$ was significantly influenced by the application of different levels of $\mathrm{N}$ and $\mathrm{K}$. Optimum application of $\mathrm{K}$ is enough to have a good harvest of sweet basil.

\section{Effects of Nitrogen and Potassium on Plant Tissue of Sweet Basil}

\section{a. Total $\mathbf{N}(\%)$}

Nitrogen is an important yield enhancing primary nutrient and is necessary for building amino acids, structural elements of proteins as well as pyrimidine and purine bases, nucleotides, and nucleic acids. Basil has substantial nutritional needs. Nitrogen favorably affects plant growth and yield (Sifola \& Barbieri 2006; Rao et al 2007; Zheljazkov et al 2008; Daneshian et al 2009).

Figure 8a shows that very high amounts of total $\mathrm{N}$ in tissue of sweet basil was observed in all treatment plants. However, the highest amount of total $\mathrm{N}$ was noticed in $\mathrm{T}_{4}$ (120-60- $60 \mathrm{~kg} / \mathrm{ha} \mathrm{N}-\mathrm{P}_{2} \mathrm{O}_{5}-\mathrm{K}_{2} \mathrm{O}$ ) under acidic soil. On the other hand, increasing amounts of $\mathrm{N}$ added into the neutral soil resulted to more or less the same values with high amounts of $\mathrm{N}$ and $\mathrm{K}$ treatments. However, on acidic soil, increasing amounts of $\mathrm{N}$ yielded increase in total $\mathrm{N}$ but this eventually decreased in $\mathrm{T}_{8}\left(60-60-180 \mathrm{~kg} / \mathrm{ha} 60 \mathrm{~kg} \mathrm{~N}-\mathrm{P}_{2} \mathrm{O}_{5}-\mathrm{K}_{2} \mathrm{O}\right)$. Meanwhile, addition of increasing levels of $\mathrm{K}_{2} \mathrm{O}$ resulted to decrease in total $\mathrm{N}$ in $\mathrm{T}_{8}\left(60-60-180 \mathrm{~kg} / \mathrm{ha} 60 \mathrm{~kg} \mathrm{~N}-\mathrm{P}_{2} \mathrm{O}_{5}-\mathrm{K}_{2} \mathrm{O}\right)$. This implies that sweet basil plants required high amounts of $\mathrm{N}$ but this should not exceed 120 to $180 \mathrm{~kg} \mathrm{~N} /$ ha as plants tend to have stunted growth and yellowing of leaves. Treatment 4 under acidic soil condition increased amounts of Total N (8.40 
$\%)$. However, high amounts of $\mathrm{N}$ applied can cause salt stress and toxicity to plants especially plant roots. Money, time, and effort would be wasted upon application of high amounts of $\mathrm{N}$.

\section{b. Total P (\%)}

Phosphorus $(P)$ is considered the most limiting nutrient next to nitrogen $(N)$ for the growth and metabolism of plants. It plays an important key role in the cellular energy transfer and storage, respiration, photosynthesis (Glass et al 1980; Usuda \& Shimogawara 1993), and as a structural component of nucleic acid and membranes (Schachtman et al 1998; Ragothama 1999).

Highest amount of total $P$ was observed on $\mathrm{T}_{3}$ (acidic soil) and $\mathrm{T}_{6}$ (neutral soil)as shown in Figure $8 \mathrm{~b}$. Sweet basil tissue had high amounts of Total $\mathrm{P}(\%)$ acquired if $\mathrm{T}_{3}$ $(0.35 \%)$ and $\mathrm{T}_{6}(0.35 \%)$ were used wherein both have $0 \mathrm{~N}$ and $\mathrm{K}$ applied. However, increasing amounts of $\mathrm{N}$ fertilizers applied yielded low amounts of $\mathrm{P}_{4^{-}} 0.20 \%$ (acidic) \& $T_{5}-0.13 \%$ (neutral), respectively. Sweet basil planted in neutral soil had the highest values of $\mathrm{P}$ as compared to acidic ones. It tends to absorb small amounts of $\mathrm{P}$ if it was planted on acidic soil. Phosphorus tends to be fixed in the soil and not available for plant use.



Legend:

$$
\begin{aligned}
& \mathrm{T}_{1}-\text { Control (No fertilizer) } \\
& \mathrm{T}_{2}-60-60-60 \mathrm{~kg} / \mathrm{ha} \mathrm{N}-\mathrm{P}_{2} \mathrm{O}_{5}-\mathrm{K}_{2} \mathrm{O} \\
& \mathrm{T}_{3}-0-60-60 \mathrm{~kg} / \mathrm{ha} \mathrm{N}-\mathrm{P}_{2} \mathrm{O}_{5}-\mathrm{K}_{2} \mathrm{O} \\
& \mathrm{T}_{4}-120-60-60 \mathrm{~kg} / \mathrm{ha} \mathrm{N}-\mathrm{P}_{2} \mathrm{O}_{5}-\mathrm{K}_{2} \mathrm{O}
\end{aligned}
$$

$$
\begin{aligned}
& \mathrm{T}_{5}-180-60-60 \mathrm{~kg} / \mathrm{ha} \mathrm{N}-\mathrm{P}_{2} \mathrm{O}_{5}-\mathrm{K}_{2} \mathrm{O} \\
& \mathrm{T}_{6}-60-60-0 \mathrm{~kg} / \mathrm{ha} \mathrm{N}-\mathrm{P}_{2} \mathrm{O}_{5}-\mathrm{K}_{2} \mathrm{O} \\
& \mathrm{T}_{7}-60-60-120 \mathrm{~kg} / \mathrm{ha} \mathrm{N}-\mathrm{P}_{2} \mathrm{O}_{5}-\mathrm{K}_{2} \mathrm{O} \\
& \mathrm{T}_{8}-60-60-180 \mathrm{~kg} / \mathrm{ha} \mathrm{N}-\mathrm{P}_{2} \mathrm{O}_{5}-\mathrm{K}_{2} \mathrm{O}
\end{aligned}
$$

Figure 8. Total $N(a)$, Total $P(b)$ and Total $K(c)$ at harvest as affected by different nitrogen and potassium doses under neutral and acidic soil condition 


\section{c. Total K(\%)}

Potassium does not form organic compounds in plants and occurs exclusively in ionic form. Thus, it is one of the most dynamic (movable) elements in a plant. The share of potassium ions in regulating plant water management, transpiration process and other important metabolic processes is highly specific. Under neutral soil condition, highest value of total $\mathrm{K}$ was observed in $\mathrm{T}_{8}\left(60-60-180 \mathrm{~kg} / \mathrm{ha} \mathrm{N}-\mathrm{P}_{2} \mathrm{O}_{5}\right.$ $\mathrm{K}_{2} \mathrm{O}$ ). Total Potassium (\%) decreased as the level of nitrogen increased, as shown in Figure 8c. However, as the level of potassium applied in the soil increased the total potassium also increased. High Total K (\%) was observed (6.68 \%) in neutral soil. This implies that increasing amounts of $\mathrm{K}$ could increase Total $\mathrm{K}$ especially under neutral soil condition.

\section{CONCLUSIONS}

Based on the results obtained, this study concludes that in terms of plant growth, the highest plant height was observed under neutral soil $\left(T_{3^{-}} 74 \mathrm{~cm}\right)$. Moreover, the highest number of primary branches was observed in $\mathrm{T}_{6}$ under neutral soil condition. In contrast, lowest number of primary branches was observed in $T_{1}$ under acidic soil condition. The highest root length was observed under neutral soil $\left(T_{1}-27.33 \mathrm{~cm}\right)$. The yield of sweet basil was significantly influenced by addition of $\mathrm{N}$ and $K$ doses. The highest fresh weight of leaf was observed in $T_{3}(118 \mathrm{~g} / \mathrm{pot})$ while the lowest was obtained in $\mathrm{T}_{5}(24.53 \mathrm{~g} / \mathrm{pot})$. Likewise, both highest fresh (216.77 $\mathrm{g} / \mathrm{pot}$ ) and dry (71.50 g/pot) herbage yield was obtained in $T_{3}$ under neutral soil condition. A similar trend was observed in fresh and dry root weight of sweet basil. The highest fresh root weight was obtained in $\mathrm{T}_{3}(9 \mathrm{~g} / \mathrm{pot})$ while the lowest was obtained in $T_{5}\left(1 \mathrm{~g} /\right.$ pot). The highest SPAD chlorophyll was obtained in $T_{2}$ (Neutral44.79). Similarly, high levels of chlorophyll a was obtained in $T_{2}$ (acidic soil- 6.36 $\mathrm{nmol} / \mathrm{ml}$ ), $\mathrm{T}_{4}$ (acidic soil- $5.96 \mathrm{nmol} / \mathrm{ml}$ ), and $\mathrm{T}_{6}$ (neutral soil- $6.48 \mathrm{nmol} / \mathrm{ml}$ ), while the highest chlorophyll b was observed in $\mathrm{T}_{2}$ (Acidic- $12.54 \mathrm{nmol} / \mathrm{ml}$ ). In terms of plant tissue, highest $\% \mathrm{~N}, \% \mathrm{P}$, and $\% \mathrm{~K}$ in the leaf tissue were recorded in $\mathrm{T}_{4}(\% \mathrm{~N}$ content of 8.40), $\mathrm{T}_{3}$ and $\mathrm{T}_{6}(\% \mathrm{P}$ of 0.35$)$, and $\mathrm{T}_{8}$ (\% K of 6.67).

The optimum combination of $\mathrm{N}$ and $\mathrm{K}$ doses that was highly favorable under both neutral and acidic condition was $\mathrm{T}_{3}\left(0-60-60 \mathrm{~kg} / \mathrm{ha} \mathrm{N}-\mathrm{P}_{2} \mathrm{O}_{5}-\mathrm{K}_{2} \mathrm{O}\right)$, indicating that sweet basil needs small amounts of $\mathrm{N}$ for its growth and yield.

The chemical properties of neutral and acidic soil were significantly affected by $\mathrm{N}$ and $\mathrm{K}$ combinations. The following treatments resulted in the highest soil chemical properties: $\mathrm{T}_{6}$ (soil pH of 5.91 ) and $\mathrm{T}_{7}$ (soil OM of $1.16 \%$ and $0.90 \%$ ). The highest total $\mathrm{N}$ was observed in $\mathrm{T}_{5}$ (Acidic- $0.27 \%$ ) and highest exchangeable $\mathrm{K}$ in $\mathrm{T}_{8}$ (Acidic- $4.29 \mathrm{meq} / 100 \mathrm{~g} \&$ Neutral- $4.19 \mathrm{meq} / 100 \mathrm{~g}$ ).

\section{RECOMMENDATIONS}

For further improvement, field experiments should be conducted to verify the results obtained under pot experiment following the treatment combinations used in the study. The optimum combination of $\mathrm{N}$ and $\mathrm{K}$ doses that was highly favorable under both neutral and acidic condition was $\mathrm{T}_{3}\left(0-60-60 \mathrm{~kg} / \mathrm{ha} \mathrm{N}-\mathrm{P}_{2} \mathrm{O}_{5}-\mathrm{K}_{2} 0\right)$, indicating that sweet basil needs small amounts of $\mathrm{N}$ for its growth and yield. Aside from 
varying the amounts of $\mathrm{N}$ and $\mathrm{K}$, it is suggested that the use of micronutrient biofortification be explored in sweet basil production

\section{ACKNOWLEDGEMENT}

The author is grateful to the Department of Science and Technology Science Education Institute (DOST-SEI) Accelerated Science and Technology Human Resource Development Program-National Science Consortium (ASTHRDP-NSC) for funding this study. Moreover, the author would also like to thank Dr. Anabella B. Tulin, Dr. Suzette B. Lina, and Dr. Marlito Jose M. Bande.

\section{REFERENCES}

Biesiada A and Kuœ A. 2010. The effect of nitrogen fertilization and irrigation on yielding and nutritional status of sweet basil (Ocimum basilicum L.). Acta Sci. Pol. Hort. Cul., 9(2), pp. 3-12

Byju G and Nedunchezhiyan M. 2004. Potassium: A key nutrient for higher tropical tuber crops production. Fertilizer News 49 (3), pp. 39-44

Chen BM, Wang ZH, Li SX, Wang GX, Song HX \& Wang XN. 2004. Effects of nitrate supply on plant growth, nitrate accumulation, metabolic concentration and nitrate reductase activity in three leafy vegetables. Plant Sci., 167, pp. 635-643

Comfort SD, Malzer GL, \& Busch RH. 1988. Nitrogen fertilization of spring wheat genotypes: Influence on root growth and soil water depletion. Agron. J. 80, pp. 114-120

Czabajski T. 1978. The effect of high doses of nitrogen on the yield of basil and savory herb. Herbal News. 7:11

Daneshian A, Gurbuz B, Cosge B \& Ipek A. 2009. Chemical components of essential oils from basil (Ocimum basilicum L.) grown at different nitrogen levels. Int. J. Nat. Eng. Sci., 3, 3, pp. 8-12

Dzida K. 2010. Nutrients contents in sweet basil (Ocimum basilicum L.) herb depending on calcium carbonate dose and cultivar. Acta Sci. Pol. Hortorum Cultus, 9 (4), pp.143-151

Dzida K and Jarosz Z. 2010. Effect of calcium carbonate and differentiated nitrogen fertilization upon the yield and chemical composition of spinach beet. Acta Sci. Pol. Hortorum Cultus, 9(3), pp. 201-210

Feil B, Thirapon R, Geisler G \& Stamp P. 1991. The impact of temperature on seedling root traits of European and tropical corn (Zea mays L.) cultivars. J. Agron. 85, pp. 287-289

Hansson AC and Andren 0. 1987. Root dynamics in barley, Lucerne, and meadow fescue investigated with a minirhizotron technique. Plant Soil 103, pp. 33-38

International Soil Reference and Information Center (ISRIC). 1995. Procedure for soil analysis. L.P. Reeuwejk (ed.).,Wageningen, The Netherlands. $106 \mathrm{pp}$

Jackson ML. 1958. Soil Chemical Analysis. Prentice-Hall, Inc., Englicliffs. N.J. p. 489 Kandil MA, Khatab ME, Ahmed SS \& Schnug E. 2009. Herbal and essential oil yield of Genovese basil (Ocimum basilicum L.) grown with mineral and organic fertilizer sources in Egypt. J. Kulturpflanzen, 61 (12):443-449 
Kuo S, Sainju UM \& Jellum E.J. 1997. Winter cover crop effects on soil organic carbon and carbohydrate. Soil Sci. Soc. Am. J. 61:145-152

Landon JR. 1991. Booker Tropical Soil Manual. Longman Scientific and Technical, Essex, England. p. 333

Matsumoto SN, Araujo GS \& Viana AES. 2013. Growth of sweet basil depending on nitrogen and potassium doses. Horticultura Brasiliera 31: 489-493

Merrill SD, Black AL \& Bauer A. 1996. Conservation tillage affects root growth of dryland spring wheat under drought. Soil Sci. Soc. Am. J. 60:575-583

Murphy $J$ and Riley JP. 1962. A Modified Single Solution Method for the Determination of Phosphorus in Natural Water. Anal. Chem. Acts

Nurzyñska-Wierdak R. 2006. The yield and chemical components of rocket and kohlrabi leaves in dependence on nitrogen and potassium fertilization. Rozpr. Nauk. AR Lublin. (in Polish)

Nurzyńska-Wierdak R and Borowski B. 2011. Dynamics of sweet basil (Ocimum basilicum L.) growth affected by cultivar and foliar feeding with nitrogen. Acta Sci. Pol. Hortorum Cultus. 10 (3):307-317

Nguyen PM, Kwee EM \& Niemeyer ED. 2010. Potassium rate alters the antioxidant capacity and phenolic concentration of basil (Ocimum basilicum L.) leaves. Food Chem. 123:1235-1241

Politycka B and Golcz A. 2004. Content of chloroplast pigments and anthocyanins in the leaves of Ocimum basilicum L. depending on nitrogen doses. Folia Horticulturae 16:23-29

Porra RJ, Thompson WA, \& Kriedemann PE. 1989. Determination of accurate extinction coefficients and simulations equations for assaying chlorophylls a and $b$ extracted with four different solvents: verification of the concentration of cholorphyll standards by atomic absorption spectroscopy. Biochimica et Biophysica. 975. pp. 384-394

Raghothama K. 1999. Phosphate acquisition. Annual review of plant biology 50: 665-693

Rao EVSP, Puttana K, Ganesha RS \& Ramesh S. 2007. Nitrogen and potassium nutrition of French basil (Ocimum basilicum Linn.). J. Spices Aromat. Plants. 16 (2):99-105

Said-Al Ahl HAH and Mahmoud AA. 2010. Effect of zinc and/or iron foliar application on growth and essential oil of sweet basil (Ocimum basilicum L.) under salt stress. Ozean J. Appl. Sci. 3 (1):97-111

Sainju UM, Singh BP \& Whitehead WF. 2005. Tillage, cover crops, and nitrogen fertilization effects on cotton and sorghum root biomass, carbon, and nitrogen. Agron. J. 97:1279-1290

Schachtman DP, Reid RJ \& Ayling SM. 1998. Phosphorus uptake by plants: from soil to cell. Plant Physio/ 116:447-453

Sifola MI and Barbier IG. 2006. Growth, yield and essential oil content of three cultivars of basil grown under different levels of nitrogen in the field. Scientia Horticulturae 108:408-413

Zheljazkov VD, Cantrell ChL, Ebelhar MW, Rowe DE \& Coker Ch. 2008. Productivity, oil content, and oil composition of sweet basil as a function of nitrogen and sulphur fertilization. Hort. Sci., 43 (5):1415-1422 
Growth, Yield, and Plant Quality of Sweet Basil

Stone LR, Goodrum DE, Jaafar MN \& Khan AH. (2001). Rooting front and water depletion depths in grain sorghum and sunflower. Agron. J. 93:1105-1110

United States Department of Agriculture (USDA). (2004). National Resource Conservation Service. Soil Survey Laboratory Methods Manual (R. Burt., ed.) USDA, NRCS Lincoln, Nebraska 